\title{
Systemic sclerosis and idiopathic interstitial pneumonia: histomorphometric differences in lung biopsies*,**
}

\author{
Esclerose sistêmica e pneumonia intersticial idiopática: \\ diferenças histomorfométricas em biópsias pulmonares
}

\author{
Edwin Roger Parra, Leandro Hideki Otani, Erika Franco de Carvalho, \\ Alexandre Ab'Saber, Vera Luiza Capelozzi
}

\begin{abstract}
Objective: The aim of this study was to examine the parenchymal and extracellular matrix remodeling process in two histologic patterns-nonspecific interstitial pneumonia (NSIP) and usual interstitial pneumonia (UIP)-in cases of idiopathic and sclerosis/systemic sclerosis (SSc)-associated interstitial pneumonia. Methods: We examined 15 cases of idiopathic NSIP, 10 cases of idiopathic UIP, 5 cases of SSc-UIP and 9 cases of SSc-NSIP. In the lung parenchyma, epithelial cells, endothelial cells and myofibroblasts were evaluated by immunohistochemical staining, whereas histochemical staining was used in order to evaluate collagen/elastic fibers in the extracellular matrix. Results: The percentage of surfactant protein A-positive epithelial cells was significantly greater in idiopathic NSIP than in SSc-NSIP, as well as being greater in idiopathic UIP than in SSc-UIP. Idiopathic NSIP and idiopathic UIP presented significantly higher immunoexpression of alpha smooth muscle actin in myofibroblasts than did SSc-NSIP and SSc-UIP. The percentage of CD34 endothelial cells in the pulmonary microvasculature was significant lower in idiopathic UIP than in SSc-UIP. The density of collagen fibers was significantly greater in idiopathic NSIP and idiopathic UIP than in SSc-NSIP and UIP. In contrast, the elastic fiber density was significantly lower in idiopathic UIP than in SSc-UIP. Conclusions: Increased collagen synthesis, destruction of elastic fibers, high myofibroblast proliferation and poor microvascularization might represent a remodeling process found in idiopathic interstitial pneumonia, whereas the reverse might represent a repair process in SSc-associated interstitial pneumonia.
\end{abstract}

Keywords: Epithelial cells; Neovascularization, pathologic; Collagen; Elastin; ldiopathic interstitial pneumonias; Scleroderma, systemic.

\section{Resumo}

Objetivo: 0 objetivo deste trabalho foi examinar o processo de remodelamento no parênquima e na matriz extracelular em dois padrões histológicos-pneumonia intersticial não-específica (PINE) e pneumonia intersticial usual (PIU)-em casos associados à esclerose idiopática/esclerose sistêmica (ES). Métodos: Investigamos 15 casos de PINE idiopática, 10 casos de PIU idiopática, 5 casos de PIU associada à ES (PIU-ES) e 9 de PINE associada à ES (PINE-ES). No parênquima pulmonar, as células epiteliais, células endoteliais e miofibroblastos foram avaliados através de coloração imuno-histoquímica, ao passo que a coloração histoquímica foi utilizada para avaliar as fibras elásticas e de colágeno na matriz extracelular. Resultados: A porcentagem de células epiteliais positivas para proteína A do surfactante foi significativamente maior nos casos de PINE idiopática do que nos de PINE-ES, assim como nos casos de PIU idiopática do que nos de PIU-ES. A PINE e a PIU idiopáticas apresentaram valores significativamente maiores de imunoexpressão de alfa actina de músculo liso nos miofibroblastos do que a PINE-ES e a PIU-ES. A porcentagem de células endoteliais CD34 na microvasculatura pulmonar foi significativamente menor na PIU idiopática do que na PIU-ES. A densidade de fibras do colágeno foi significativamente maior em ambas as formas idiopáticas de PINE e PIU do que na PINE-ES e PIU-ES. Em contraste, a densidade de fibras elásticas foi significativamente menor na PIU idiopática do que na PIU-ES. Conclusões: A síntese aumentada de colágeno, a destruição de fibras elásticas, a alta proliferação miofibroblástica e a microvascularização diminuída podem representar um processo de remodelamento encontrado na pneumonia intersticial idiopática, enquanto o reverso pode representar mais um processo de reparo na pneumonia intersticial associada à ES.

Descritores: Células epiteliais; Neovascularização patológica; Colágeno; Elastina; Pneumonia intersticial idiopática; Esclerose sistêmica.

* Study carried out in the Pathology Department of the University of São Paulo School of Medicine, São Paulo, Brazil.

Correspondence to: Edwin Roger Parra or Vera Luiza Capelozzi. Departamento de Patologia, Faculdade de Medicina da Universidade de São Paulo, Av. Dr. Arnaldo, 455, CEP 01246-903, São Paulo, SP, Brasil.

Tel 5511 3061-7427. E-mail: erparra20003@yahoo.com.br or vcapelozzi@lim05.fm.usp.br

Financial support: This study received financial support from the Fundação de Amparo à Pesquisa do Estado de São Paulo (FAPESP, Foundation for the Support of Research in the State of São Paulo) and from the Conselho Nacional de Desenvolvimento Cientifico e Tecnológico (CNPq, National Council for Scientific and Technological Development).

Submitted: 9 September 2008. Accepted, after review: 5 December 2008.

**A versão completa em português deste artigo está disponível em www.jornaldepneumologia.com.br 


\section{Introduction}

Pulmonary involvement occurs more frequently in systemic sclerosis (SSc) than in other collagen vascular disorders, representing a significant cause of morbidity and mortality in this patient population. ${ }^{(1-4)}$ The most common manifestation of pulmonary involvement in SSc is interstitial fibrosis, which occurs in approximately $80 \%$ of cases, and pulmonary arterial hypertension, which occurs in up to $15 \% .{ }^{(5)}$ Many authors have shown ${ }^{(6-8)}$ that a number of histologic patterns of interstitial fibrosis associated with collagen vascular disorders have a better prognosis than does lone cryptogenic fibrosing alveolitis, also known as idiopathic pulmonary fibrosis.

The most recent modifications to the system of classifying the various types of idiopathic interstitial pneumonia (IIP) were made in 2002. ${ }^{(9)}$ The histologic pattern of nonspecific interstitial pneumonia (NSIP), now recognized as an IIP subgroup, has a prognosis intermediate between that of usual interstitial pneumonia (UIP) and that of other IIPs, such as desquamative interstitial pneumonia/respiratory bronchiolitis interstitial lung disease (ILD) and cryptogenic organizing pneumonia. ${ }^{(10-13)}$

Although histologic patterns of NSIP and UIP are known to occur in SSc, ${ }^{(9,14)}$ their prevalence, as well as their relationship with clinical parameters, response to treatment, and prognosis, are poorly known. One group of authors classified histologic appearances of surgical lung biopsies performed in patients with SSc and found that NSIP was the most common histologic pattern in patients with SSc, although the outcome was linked more strongly to disease severity at presentation and serial carbon monoxide diffusing capacity trends than to histopathologic findings. Although the NSIP and UIP histologic patterns are similar for idiopathic or SSc pulmonary fibrosis (SSc-NSIP and SSc-UIP), recent studies have demonstrated that the latter has a better prognosis, and that the clinical features of SSc-NSIP and SSc-UIP generally improve with corticosteroid therapy. ${ }^{(6)}$ This finding is probably related to differences in the lung repair/remodeling process, as well as to the effects of the treatment given in an attempt to avoid irreversible damage and to increase survival. ${ }^{(10)}$

Molecular markers in epithelial cells, myofibroblasts, endothelial cells and the extracellular matrix (collagen/elastic system fibers) are increasingly recognized as playing an important role in regeneration, repair and remodeling following lung injury. Variations in these markers might also explain differences in the pathogenesis of fibrotic lung diseases, either idiopathic or SSc-associated. We postulate that going back to basics will bring us new ideas for better understanding the pathophysiological differences between IIP and interstitial pneumonia associated with connective tissue diseases.

The aim of this study was to examine the parenchymal and extracellular matrix remodeling process in idiopathic and SSc-associated interstitial pneumonia, focusing on the UIP and NSIP histologic patterns.

\section{Methods}

Between 1980 and 2002, open lung biopsy specimens were obtained from 39 patients: 15 with idiopathic NSIP, 10 with idiopathic UIP, 5 with SSc-UIP and 9 with SSc-NSIP, according to the criteria outlined by the Thoracic Society/ European Consensus Group ${ }^{(9)}$ and American Rheumatism Association Diagnostic and Therapeutic Criteria Committee. ${ }^{(15)}$

The biopsy specimens were reviewed independently by two pathologists. In most cases of discordance, a consensus was reached after a review by a third pathologist. For the remaining controversial cases, a consensus opinion was achieved by a final face-to-face meeting of the pathologists, all of whom were blinded to the clinical information.

Temporally homogenous septal inflammatory fibrotic thickening and epithelial cell proliferation were considered characteristic of NSIP. ${ }^{(16)}$ The UIP pattern was characterized as alternating areas of normal parenchyma, alveolar collapse, honeycombing and severe mural organizing fibrosis, defined as sites of active remodeling overlying fibrous airspace walls, indicative of temporal heterogeneity, or overlying normal rigid pulmonary structures (interlobular septa) in the form of fibroblast foci and granulation tissue. ${ }^{(9)}$

In the lung parenchyma, epithelial cells, endothelial cells and myofibroblasts were evaluated through immunohistochemical staining using the avidin-biotin immunoperoxidase complex technique. For epithelial cells, the antibodies used were anti-cytokeratin 7 (anti-CK7, 

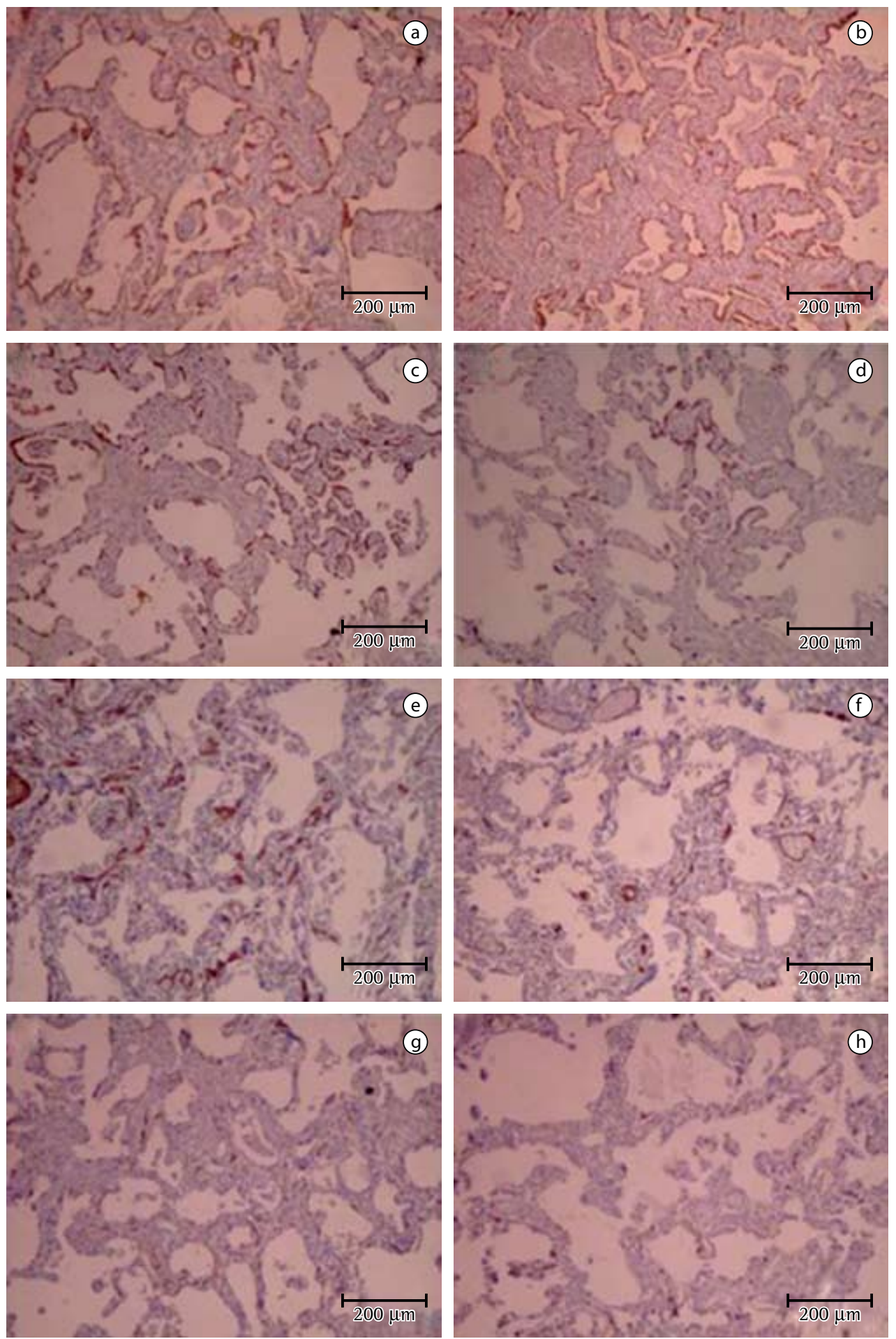

Figure 1 - Histologic representation of idiopathic NSIP and SSc-NSIP. Immunoexpression of CK7 in the continuous basement membrane in idiopathic NSIP (a) and SSc-NSIP (b). SP-A-positive epithelial cells are more numerous in idiopathic NSIP (c) than in SSc-NSIP (d). Myofibroblasts present higher expression of $\alpha$-SMA in idiopathic NSIP (e) than in SSc-NSIP (f). Small capillary vessels are sparse in idiopathic NSIP (g) and dense in SSc-NSIP (h). Immunostaining: for CK7 (a and b, $\times 100$ ); for SP-A (c and d, $\times 100$ ); for $\alpha$-SMA (e and f, $\times 100$ ); and for CD34 (g and $h, \times 100$ ). CK7: cytokeratin 7; SP-A: surfactant protein A; $\alpha$-SMA: alpha smooth muscle actin; NSIP: nonspecific interstitial pneumonia; SSc: systemic sclerosis; and UIP: usual interstitial pneumonia. 

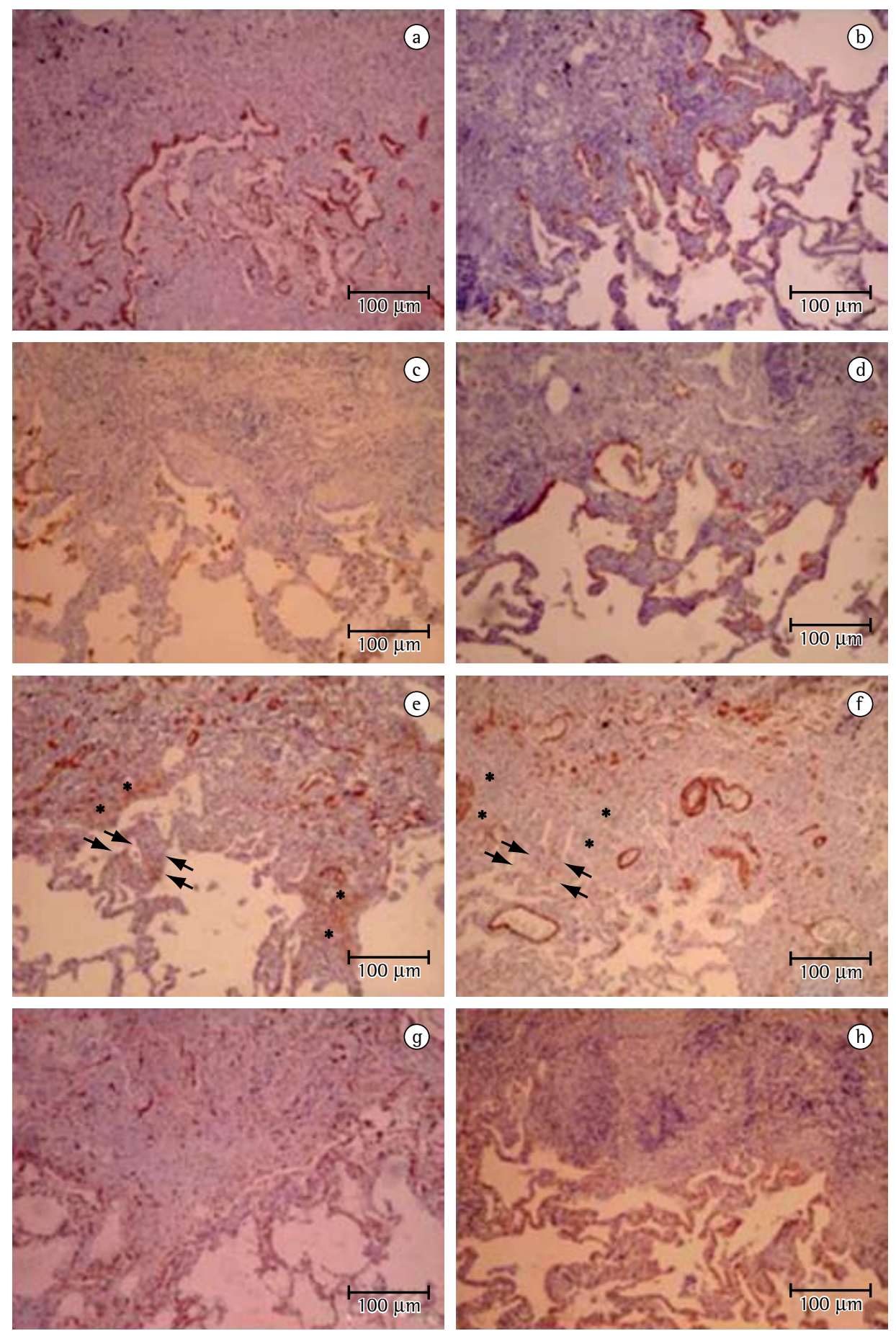

Figure 2 - Histologic representation of idiopathic UIP and SSc-UIP. Similar immunoexpression of CK7 in idiopathic UIP (a) and SSc-UIP (b); similar immunoexpression of SP-A in idiopathic UIP (c) and SSc-UIP (d). In areas of mural organization (stars) and alveolar collapse (arrows), proliferation of highly active myofibroblasts can be seen overlying the original surface of the airspace in idiopathic UIP (e) when compared with SSc-UIP (f). Immunoexpression of different vascular markers in idiopathic and SSc-UIP. Minimal immunoexpression of the endothelial cell marker (CD34) in idiopathic UIP (g) when compared with SSc-UIP (h). Immunostaining: for CK7 (a and b, x 100); for SP-A (c and d, x100); for $\alpha$-SMA (e and f, x 100); and for CD34 ( $g$ and h, $\times 100$ ). CK7: cytokeratin 7; SP-A: surfactant protein A; $\alpha$-SMA: alpha smooth muscle actin; NSIP: nonspecific interstitial pneumonia; SSc: systemic sclerosis; and UIP: usual interstitial pneumonia. 

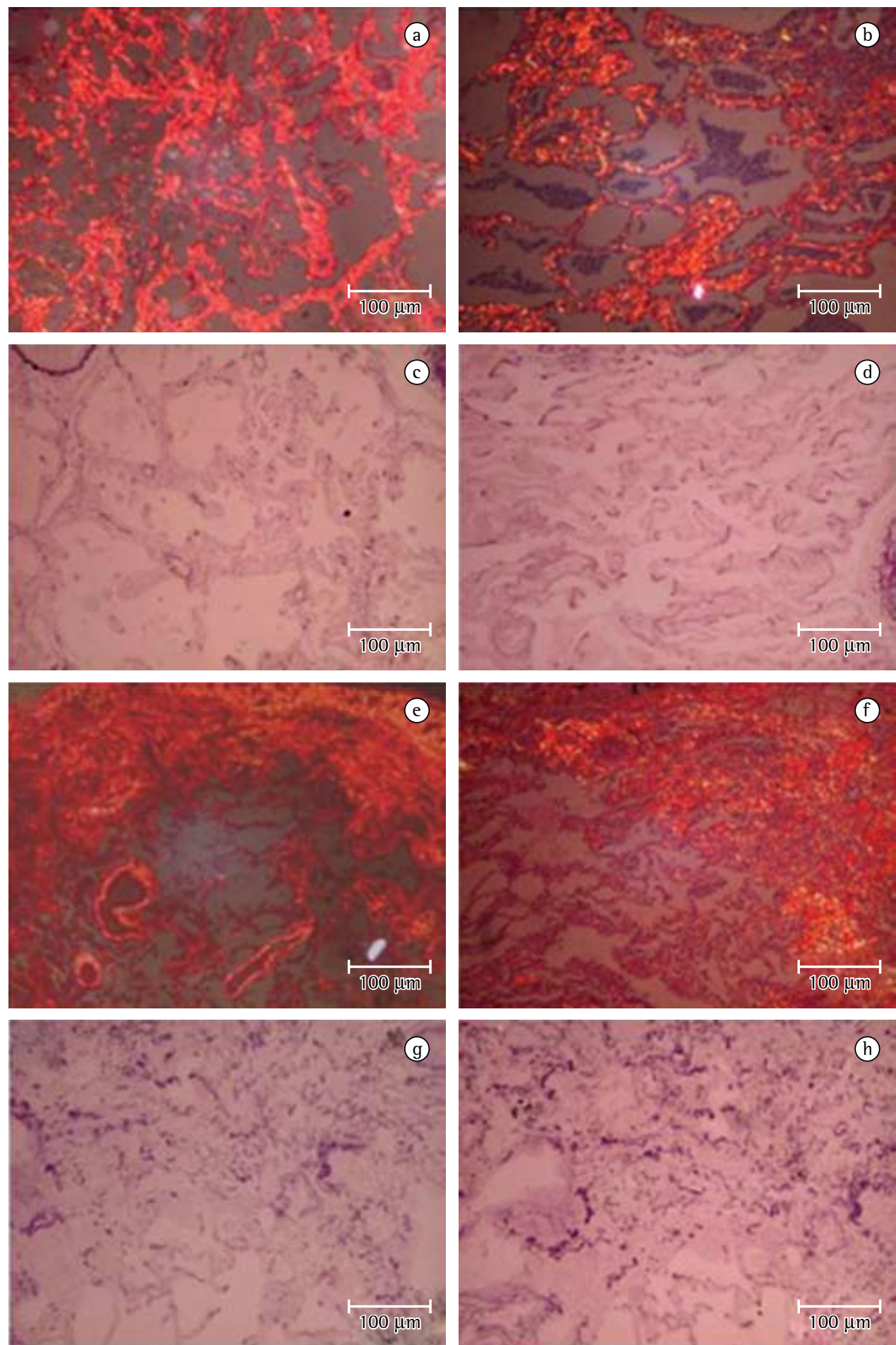

Figure 3 - Strong, homogeneous red-orange birefringence in the interstitium in idiopathic NSIP (a), contrasting with the low red-orange birefringence observed in SSc-NSIP (b). Elastic fiber density is lower in idiopathic NSIP (c) than in SSc-NSIP (d). Strong, heterogeneous red-orange birefringence found in the interstitium in idiopathic UIP (e), contrasting with the low red-orange birefringence observed in SSc-UIP (f) and low red-orange birefringence is observe in idiopathic UIP (g) when compared with SSc-UIP (h). Picrosirius-polarization (a, b, e and $f, \times 100$ ); and Weigert's resorcin-fuchsin (c, $d, g$ and $h, \times 100$ ). NSIP: nonspecific interstitial pneumonia; SSc: systemic sclerosis; and UIP: usual interstitial pneumonia. 
Clone OV-TL 12/30, 1:100; Dako, Glostrup, Denmark), which recognizes type 1/type 11 pneumocytes and bronchial epithelial cells, and surfactant protein A (SP-A, Clone PE10, 1:800; Dako, Carpinteria, (A, USA) which recognizes type 11 pneumocytes and Clara cells. Endothelial cells were characterized using an anti-CD34 monoclonal antibody (Clone QBEnd/10, 1:400; Novocastra Laboratories Ltd, Newcastle, UK). Myofibroblasts were evaluated with anti-alpha smooth muscle actin (anti- $\alpha$-SMA; A-AML, Clone 1A4, 1:20; Dako, Glostrup, Denmark) at a $1: 20$ dilution, which recognizes the myofibroblasts in benign and reactive lesions.

Positive epithelial cells (CK7 and SP-A), endothelial cells (CD34) and myofibroblasts $(\alpha-S M A)$ were analyzed without image analysis, since the eyepiece-only method is more specific for quantifying the structures and forms that would present similar densities in the image analysis. In brief, we used a 400x eyepiece containing a systematic point-sampling grid with 100 points and 50 lines in order to count the fraction of lines overlying positively stained structures. ${ }^{(17)}$ In the UIP histologic pattern, the temporal heterogeneity and alternating areas of remodeling represented three different areas in the same biopsy. As usual, we quantified
10 fields per biopsy when the distribution of the lesions were homogeneous, as in the NSIP histologic pattern, whereas we quantified 30 fields per biopsy in cases of UIP: 10 in normal areas; 10 in intermediate areas (alveolar collapse); and 10 in remodeling areas (mural fibrosis and honeycombing areas). We averaged the microscopic fields to obtain the final percentage of stained structures.

The extracellular matrix was evaluated for collagen/elastic fibers by histochemical staining. Collagen fiber characterization was performed using $0.2 \%$ solution of Sirius red (Direct Red 80, C. 1. 35780; Aldrich, Milwaukee, Wl, USA) dissolved in aqueous saturated picric acid. ${ }^{(18)}$ The enhancement of collagen birefringence promoted by the Picrosirius-polarization method is specific for collagenous structures composed of aggregates of oriented molecules. Elastic fibers were characterized using Weigert's resorcin-fuchsin method, after oxidation. ${ }^{(18)}$ This method allows the selective identification of the three types of elastic system fibers (oxytalan; elaunin; and fully developed elastic fibers).

The quantification of collagen/elastic fibers in interstitial walls was performed using an image analysis system. The system consists of an Olympus camera, coupled to an Olympus micro-

Table 1 - Descriptive analysis of the cases evaluated.

\begin{tabular}{|c|c|c|c|c|c|c|}
\hline \multirow[t]{3}{*}{ Group } & \multicolumn{6}{|c|}{ Marker } \\
\hline & CK7 & SP-A & $\alpha-S M A$ & CD34 & Collagen & Elastic \\
\hline & \multicolumn{6}{|c|}{$\%$, mean \pm SEM } \\
\hline ldiopathic NSIP $(n=15)$ & $11.45 \pm 0.90$ & $7.02 \pm 0.74$ & $8.07 \pm 057$ & $7.97 \pm 0.58$ & $14.46 \pm 0.77$ & $7.25 \pm 0.81$ \\
\hline SSc-NSIP $(n=9)$ & $11.52 \pm 1.22$ & $4.62 \pm 0.64$ & $4.03 \pm 0.97$ & $9.83 \pm 0.39$ & $8.95 \pm 0.72$ & $9.82 \pm 0.79$ \\
\hline Idiopathic UIP (n = 10) & $15.43 \pm 3.52$ & $1.31 \pm 0.26$ & $12.78 \pm 1.2$ & $3.97 \pm 0.32$ & $20.54 \pm 1.38$ & $5.73 \pm 0.90$ \\
\hline SSc-UIP (n = 5) & $12.22 \pm 3.84$ & $0.99 \pm 0.18$ & $9.43 \pm 0.91$ & $5.49 \pm 0.44$ & $14.47 \pm 0.73$ & $8.72 \pm 0.78$ \\
\hline \multirow[t]{3}{*}{ Comparison } & \multicolumn{6}{|c|}{ Marker } \\
\hline & CK7 & SP-A & $\alpha-S M A$ & CD34 & Collagen & Elastic \\
\hline & \multicolumn{6}{|c|}{ Bonferroni significance } \\
\hline $\begin{array}{l}\text { ldiopathic NSIP vs. } \\
\text { SSc-NSIP }\end{array}$ & $p>0.05$ & $p>0.05$ & $p>0.05$ & $p>0.05$ & $p>0.05$ & $p>0.05$ \\
\hline $\begin{array}{l}\text { ldiopathic NSIP vs. } \\
\text { ldiopathic UIP }\end{array}$ & $p<0.01$ & $p<0.01$ & $p<0.01$ & $p<0.01$ & $p<0.01$ & $p<0.01$ \\
\hline $\begin{array}{l}\text { ldiopathic NSIP vs. } \\
\text { SSc-UIP }\end{array}$ & $p<0.01$ & $p<0.01$ & $p<0.01$ & $p<0.01$ & $p<0.01$ & $p<0.01$ \\
\hline $\begin{array}{l}\text { SSc-NSIP vS. } \\
\text { ldiopathic UIP }\end{array}$ & $p<0.01$ & $p<0.01$ & $p<0.01$ & $p<0.01$ & $p<0.01$ & $p<0.01$ \\
\hline $\begin{array}{l}\text { ldiopathic UIP vs. } \\
\text { SSc-UIP }\end{array}$ & $p>0.05$ & $p>0.05$ & $p>0.05$ & $p>0.05$ & $p>0.05$ & $p>0.05$ \\
\hline
\end{tabular}

CK7: cytokeratin 7; SP-A: surfactant protein A; $\alpha$-SMA: alpha smooth muscle actin; NSIP: nonspecific interstitial pneumonia; SSc: systemic sclerosis; and UIP: usual interstitial pneumonia. 
scope (Olympus Optical, Tokyo, Japan), which transmits the images to a computer monitor. To process the images, a digitizing system (Oculus TCX; Coreco Inc, St. Laurent, Quebec, Canada) was used in conjunction with the software ImagePro Plus 6.0 (Media Cybernetics, Silver Spring, MD, USA). We quantified 10 fields per biopsy in cases of NSIP, whereas we quantified 30 fields per biopsy in cases of UIP: 10 in normal areas; 10 in intermediate areas (alveolar collapse); and 10 in remodeling areas (mural fibrosis and honeycombing areas)..(19,20) The thresholds for fibers of the collagenous and elastic systems were established for each slide, after enhancing the contrast up to a point at which the fibers were easily identified as black (elastic) or birefringent (collagen) bands. The area occupied by the fibers was determined through digital densitometric recognition, by adjusting the threshold level of measurement up to the gray density of the fibers of the collagenous and elastic systems. Bronchi and blood vessels were carefully avoided during the measurements.

To normalize the data, the area occupied by the cells and fibers, measured in each alveolar septum, was divided by the length of each septum studied (to avoid any bias secondary to septal edema or alveolar collapse). Septal length was carefully measured through the eyepiece and with the image analysis system, using points and a cursor that allows the free determination of the length of the basal lamina even if there is associated septal shortening by atelectasis or retraction. ${ }^{(19)}$ The measurements of cells and fibers by morphometry (stereology and digital imaging) are corrected taking into account the septal length. The results express the area of collagen and elastic fibers per total area of interstitial wall, expressed as a percentage.

For each parameter evaluated, the mean and standard error of the mean were plotted in tables. Before proceeding to a formal analysis of data, descriptive statistics were recorded and graphically illustrated. Independent-sample paired t-tests and ANOVA with Bonferroni test for multiple comparisons were performed when appropriate. All statistical procedures were performed using the Statistical Package for the Social Sciences for Windows, version 10.0 (SPSS Inc., Chicago, IL, USA). The level of significance was set at $p \leq 0.05$.

\section{Results}

The NSIP pattern was characterized by temporally homogenous thickening of the alveolar septa by fibroblasts embedded in an edematous stroma. The fibroblasts in septal thickening due only to inflammation did not show the contractile myofibroblast phenotype as in mural fibrosis of UIP, representing areas of interstitial reaction with no damage to the basement membrane. This was confirmed by the continuous basement membrane underlying CK7 and SP-A-positive epithelial cells (Figure 1).

The UIP pattern was characterized by alternating areas of normal parenchyma, alveolar collapse, honeycombing, and severe mural organizing fibrosis. In areas of alveolar collapse, proliferation of highly active myofibroblasts was observed overlying the original surface of the airspace (Figure 2). There were no epithelial cells overlying the myofibroblasts. We observed only a few inflammatory cells and thin collagen fibers, among which we observed neither vascular structures nor elastic fibers. In the honeycombing areas, CK-positive/SP-A-negative epithelial cells recovered the focus of mural fibrosis (Figure 2). The myofibroblasts showed less expression of $\alpha$-SMA and assumed the characteristic appearance of fibroblast foci. Thin collagen fibers were more abundant, without the thick counterpart, and thin elastic fibers were occasionally noted (Figure 3). The adjacent airspace wall showed prominent SP-A-positive pneumocytes or bronchiolar epithelial recovery. Mural organizing fibrosis areas demonstrated a continuous epithelial lining with scattered SP-A-positive cells overlying the basement membrane.

Mesenchymal cells displayed a spindle configuration and focal $\alpha$-SMA expression. Thick collagen fibers and thin elastic fibers were observed running parallel to the surface, settling the tissue by apposition, and occasional small capillary vessels were detected. Healed sites showed complete original epithelial lining overlying a continuous basement membrane. The subjacent stroma was poorly vascularized and consisted of $\alpha$-SMA-negative fibroblasts, thick collagen bundles, and irregularly arranged thin and thick frayed elastic fibers (Figure 3). The adjacent airspace wall was also lined by the original epithelium. Mural fibrosis was observed most commonly in the healing phase. 

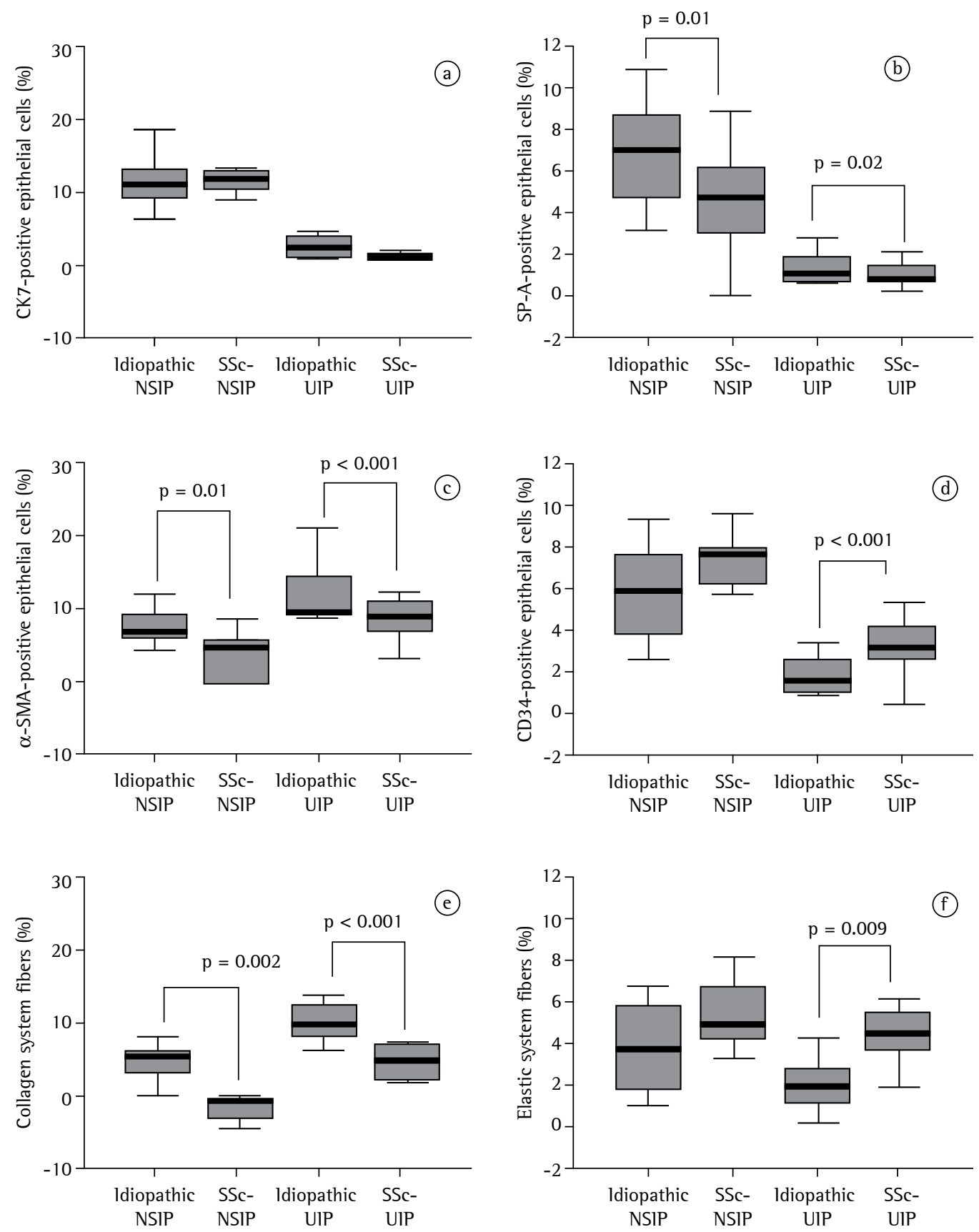

Figure 4 - Graphic illustration of epithelial density (CK7 and SP-A; a and b); myofibroblast density and microvascular density ( $\alpha$-SMA and CD34; c and d); and collagen/elastic system fibers density in interstitium (e and f) of idiopathic and SSc-associated interstitial pneumonia with NSIP and UIP histologic patterns. CK7: cytokeratin 7; SP-A: surfactant protein A; $\alpha$-SMA: alpha smooth muscle actin; NSIP: nonspecific interstitial pneumonia; SSc: systemic sclerosis; and UIP: usual interstitial pneumonia.

There were no statistical differences between the idiopathic forms and the SSc-associated forms in terms of the CK7-positive epithelial cell counts (Table 1 and Figure 4a). However, the percentage of SP-A-positive epithelial cells was significantly greater in idiopathic NSIP than in SSc-NSIP (7.02 \pm 0.74 vs. $4.62 \pm 0.64 ; p=0.01$; Table 1 and Figure $4 \mathrm{~b}$ ), as well as being significantly greater in idiopathic UIP than in SSc-UIP $(p=0.02)$. 
1diopathic NSIP presented significantly higher percentages of $\alpha$-SMA-positive cells than did SSc-NSIP (7.88 \pm 0.57 vs. $4.63 \pm 1.23$; $p=0.01)$. The percentages of $\alpha$-SMA-positive cells were also significantly greater in idiopathic UIP than in SSc-UIP (12.78 \pm 1.27 vs. $9.68 \pm 1.61$; $p<0.001$; Figure 4c).

As can be seen in Figure $4 \mathrm{~d}$, the percentages of CD34-positive endothelial cells in the pulmonary microvasculature were comparable between idiopathic NSIP and SSc-NSIP $(8.01 \pm 0.54$ vs. $9.33 \pm 0.28 ; p>0.05)$, although these values were lower in idiopathic UIP than in SSc-UIP (3.97 \pm 0.32 vs. $5.30 \pm 0.81 ; p<0.001$ ).

The density of collagen fibers was significantly higher in idiopathic NSIP and UIP $(14.00 \pm 0.84$ and $20.54 \pm 1.38 ; p=0.002)$ than in SSc-NSIP and UIP $(8.84 \pm 1.06$ and $14.77 \pm 0.98 ; p<0.001$, as can be seen in Table 1 and Figure 4e. In contrast, the elastic fiber density was lower in idiopathic NSIP than in SSc-NSIP (7.41 \pm 0.75 vs. $10.06 \pm 1.13)$, although the difference was not statistically significant ( $p=0.07$; Table 1 and Figure 4f). A significant difference in elastic fiber density was found between idiopathic UIP and SSc-UIP (5.73 \pm 0.90 vs. $9.57 \pm 1.01 ; p=0.009)$.

In idiopathic NSIP and idiopathic UIP, a positive correlation was found between epithelial and endothelial cells $(r=0.70 ; p<0.01)$, whereas epithelial cells were found to correlate negatively with myofibroblasts $(r=-0.52 ; p<0.01)$ and collagen fibers $(r=-0.44 ; p=0.002)$. Myofibroblasts correlated negatively with endothelial cells $(r=-0.70 ; p<0.01)$, negatively with elastic fibers $(r=-0.31 ; p=0.03)$ and positively with collagen fibers $(r=0.73, p<0.01)$. Endothelial cells correlated negatively with collagen fibers $(r=-0.70, p<0.01)$. A negative correlation was found between collagen fibers and elastic fibers $(r=-0.41 ; p<0.01)$.

\section{Discussion}

The present study examined the parenchymal and extracellular matrix remodeling processes in the UIP and NSIP histologic patterns of idiopathic and SSc-associated interstitial pneumonia. We found differences among these groups in specialized epithelial and myofibroblast cell populations. For example, activation of specialized SP-A-positive epithelial cells and myofibroblasts was greater in the idiopathic forms. It is of note that the percentages of CD34-positive endothelial cells in the pulmonary microvasculature were comparable between the two NSIP patterns, whereas it was lower in idiopathic UIP than in SSc-UIP. In addition, both idiopathic groups presented increased collagen fiber density, although elastosis was only observed in idiopathic UIP.

The process of pulmonary remodeling undoubtedly involves a complex and dynamic interplay among parenchymal and interstitial constituents. Among these, the epithelium, the microvasculature and the extracellular matrix are thought to be important because they are responsible for the architectural integrity. For example, alveolar collapse has been described as an important form of active remodeling in diffuse alveolar damage. ${ }^{(20)}$

The destruction of the epithelial lining and the apposition of two denuded septa are followed by re-epithelialization of the air-exposed surface, leading to permanent loss of alveoli. In our study, SP-A-positive epithelial cell counts were significantly higher in idiopathic NSIP than in SSc-NSIP, indicating that the proliferation of type 11 pneumocytes to re-epithelialize the denuded basement membrane is more regenerative in idiopathic NSIP, suggesting greater disruption of the basement membrane and adequate substrate for initiating the intra-alveolar fibrogenic process. In fact, we found similar numbers of SP-A-positive cells in idiopathic UIP, also indicating a severe degree of alveolar collapse. This finding is in line with those of other authors. ${ }^{(21)}$

We also demonstrated that $\alpha$-SMA-positive cell counts were significantly higher in idiopathic NSIP than in SSc-NSIP, as well as being higher in idiopathic UIP than in SSc-UIP. These findings in the idiopathic histologic pattern probably reflect what occurs in the alveolar spaces after extensive epithelial basement membrane denudation by necrosis and sloughing of type 1 pneumocytes, as previously reported. ${ }^{(22)}$

Proliferating intraluminal fibroblasts have a contractile phenotype, presenting SMA-type filaments in their cytoplasm, ${ }^{(23,24)}$ and represent the main source of collagen production. ${ }^{(25)}$ Ultrastructural studies have demonstrated that, during the incorporation of intra-alveolar fibrosis, these myofibroblasts attach to the luminal surface of the epithelial basement 
membrane (EBM) remnants. The epithelial cells that transiently overlie the intra-alveolar fibroblastic masses prior to the makeup of the new EBM are undifferentiated and unstable epithelial cells that work as a dressing. The assembly of a stable and completely differentiated epithelium occurs only when a continuous EBM layer is formed over the intra-alveolar fibroblasts. These dynamic healing processes result in different endpoints via diverse remodeling patterns, as delineated in a study involving several types of ILD ${ }^{(26)}$ : intraluminal buds, obliterative fibrosis and mural fibrosis.

Our group recently demonstrated associations between the extracellular matrix and vascular remodeling. ${ }^{(27,28)}$ The results suggest that extracellular matrix components not only participate in the remodeling process, and thus allowing changes in vascularization, but also regulate endothelial proliferation. We have also shown that collagen type $\mathrm{V}$ is increased in UIP, and that is the most important predictor of survival. Our primary intention in the present study was to evaluate the parenchyma (CK7and SP-A-positive epithelial cells) and the septal interstitium (CD34-positive endothelial cells and $\alpha$-SMA-positive myofibroblasts), as well as components of the extracellular matrix (collagen and elastic fibers), in cases of idiopathic and SSc-associated interstitial pneumonia. However, the involvement of type $\mathrm{V}$ collagen should be studied in a prospective study that includes new cases of SSc-associated interstitial pneumonia.

Various authors have shown the morphological sequential evolution of UIP. ${ }^{(29)}$ Alveolar epithelial injury is the initial event, necrosis and sloughing of pneumocytes resulting in the reduction of epithelial cells and denudation of the EBM. Most of the EBM is destroyed, with a reduction in the number of elastic fibers. ${ }^{(21)} \mathrm{ln}$ addition, it has been shown that the endothelial cells are only mildly damaged by the pronounced capillarization of the interstitium in UIP and NSIP, which is reminiscent of granulation tissue seen in wound healing. ${ }^{(30)}$ In the present study, we demonstrated that there is considerably less microvascular density in the interstitium of patients with idiopathic NSIP than in that of those with SSc-NSIP. To our knowledge, this is the first report of a comparison between IIP and SSc-associated interstitial pneumonia. The strong association between pulmonary fibrosis and lower microvascular density could contribute to the more rapid progression in idiopathic diseases.

The collagen and elastic systems, the major fibrous components of the extracellular matrix, have been addressed in previous reports on IIP, in an attempt to establish a correlation between alterations in their content and possible deleterious consequences for pulmonary function. ${ }^{(19)}$ Several studies previously carried out by our group have shown that lung collagen and elastic contents are increased in both acute and chronic lLDs, demonstrating that significant remodeling of the alveolar structure occurs in these situations. ${ }^{(19)}$ In the present study, we demonstrated that the density of collagen fibers was significantly greater in both forms of IIP (NSIP and UIP), although low elastic fiber density was mainly found in idiopathic NSIP.

The low microvascularization, as well as the increased deposition of collagen fibers (organizing fibrosis) and destruction of elastic fibers, in idiopathic UIP and idiopathic NSIP are thought to maintain the activity of the process and might prevent resolution; the capillary network diminishes progressively from the early to the late phase, whereas the opposite occurs in incorporating fibrosis. ${ }^{(27,30)}$ In fact, establishing a vascular supply is a sine qua non requisite for any newly formed viable tissue (proliferative phase endometrium, neoplastic tissues, etc.) and its absence is synonymous with atrophy. In the present study, we confirmed that direct epithelial integrity is important to maintaining tissue homeostasis mainly in idiopathic NSIP and UIP, whereas the integrity of endothelial (CD34positive) cells is crucial for tissue architecture in SSc-NSIP and SSc-UIP.

In summary, we found that the parenchymal and extracellular remodeling process in SSc-associated interstitial pneumonia is different from that occurring in IIP. Increased collagen synthesis, destruction of elastic fibers, high myofibroblast proliferation and poor microvascularization might represent a more definitive remodeling process in IIP, whereas the reverse might represent a repair process in SSc-associated interstitial pneumonia. These two different forms of parenchymal repair might represent different adaptive responses to injury in these forms of ILD. 


\section{Acknowledgments}

This study was supported by the following Brazilian agencies: the Conselho Nacional de Desenvolvimento Científico e Tecnológico (CNPq, National Council for Scientific and Technological Development) and the Fundação de Amparo à Pesquisa do Estado de São Paulo (FAPESP, Foundation for the Support of Research in the State of São Paulo).

\section{References}

1. Minai OA, Dweik RA, Arroliga AC. Manifestations of scleroderma pulmonary disease. Clin Chest Med. 1998;19(4):713-31, viii-ix.

2. Cheema GS, Quismorio FP Jr. Interstitial lung disease in systemic sclerosis. Curr Opin Pulm Med. 2001;7(5):283-90.

3. Silver RM. Interstitial lung disease of systemic sclerosis. Int Rev Immunol. 1995;12(2-4):281-91.

4. Shahin AA. Pulmonary involvement in systemic sclerosis. Treat Respir Med. 2006;5(6):429-36.

5. Ramirez A, Varga J. Pulmonary arterial hypertension in systemic sclerosis: clinical manifestations, pathophysiology, evaluation, and management. Treat Respir Med. 2004;3(6):339-52.

6. Wells AU, Cullinan P, Hansell DM, Rubens MB, Black CM, Newman-Taylor AJ, et al. Fibrosing alveolitis associated with systemic sclerosis has a better prognosis than lone cryptogenic fibrosing alveolitis. Am J Respir Crit Care Med. 1994;149(6):1583-90.

7. Wells AU, Hansell DM, Rubens MB, Cailes JB, Black CM, du Bois RM. Functional impairment in lone cryptogenic fibrosing alveolitis and fibrosing alveolitis associated with systemic sclerosis: a comparison. Am J Respir Crit Care Med. 1997;155(5):1657-64.

8. Park JH, Kim DS, Park IN, Jang SJ, Kitaichi M, Nicholson AG, et al. Prognosis of fibrotic interstitial pneumonia: idiopathic versus collagen vascular disease-related subtypes. Am J Respir Crit Care Med. 2007;175(7):705-11.

9. American Thoracic Society; European Respiratory Society. American Thoracic Society/European Respiratory Society International Multidisciplinary Consensus Classification of the ldiopathic Interstitial Pneumonias. This joint statement of the American Thoracic Society (ATS), and the European Respiratory Society (ERS) was adopted by the ATS board of directors, June 2001 and by the ERS Executive Committee, June 2001. Am J Respir Crit Care Med. 2002;165(2):277-304.

10. Daniil ZD, Gilchrist FC, Nicholson AG, Hansell DM, Harris J, Colby TV, et al. A histologic pattern of nonspecific interstitial pneumonia is associated with a better prognosis than usual interstitial pneumonia in patients with cryptogenic fibrosing alveolitis. Am J Respir Crit Care Med. 1999;160(3):899-905.

11. Travis WD, Matsui K, Moss J, Ferrans VJ. Idiopathic nonspecific interstitial pneumonia: prognostic significance of cellular and fibrosing patterns: survival comparison with usual interstitial pneumonia and desquamative interstitial pneumonia. Am J Surg Pathol. 2000;24(1):19-33.

12. Nicholson AG, Colby TV, du Bois RM, Hansell DM, Wells $\mathrm{AU}$. The prognostic significance of the histologic pattern of interstitial pneumonia in patients presenting with the clinical entity of cryptogenic fibrosing alveolitis. Am J Respir Crit Care Med. 2000;162(6):2213-7.

13. Cottin V, Donsbeck AV, Revel D, Loire R, Cordier JF. Nonspecific interstitial pneumonia. Individualization of a clinicopathologic entity in a series of 12 patients. Am J Respir Crit Care Med. 1998;158(4):1286-93.

14. Flaherty KR, Travis WD, Colby TV, Toews GB, Kazerooni EA, Gross BH, et al. Histopathologic variability in usual and nonspecific interstitial pneumonias. Am J Respir Crit Care Med. 2001;164(9):1722-7.

15. Preliminary criteria for the classification of systemic sclerosis (scleroderma). Subcommittee for scleroderma criteria of the American Rheumatism Association Diagnostic and Therapeutic Criteria Committee. Arthritis Rheum. 1980;23(5):581-90.

16. Katzenstein AL, Myers JL. Idiopathic pulmonary fibrosis: clinical relevance of pathologic classification. Am J Respir Crit Care Med. 1998;157(4 Pt 1):1301-15.

17. Gundersen HJ, Bendtsen TF, Korbo L, Marcussen N, Møller A, Nielsen K, et al. Some new, simple and efficient stereological methods and their use in pathological research and diagnosis. APMIS. 1988;96(5):379-94.

18. Montes GS. Structural biology of the fibres of the collagenous and elastic systems. Cell Biol Int. 1996;20(1):15-27.

19. Rozin GF, Gomes MM, Parra ER, Kairalla RA, de Carvalho CR, Capelozzi VL. Collagen and elastic system in the remodelling process of major types of idiopathic interstitial pneumonias (IIP). Histopathology. 2005;46(4):413-21.

20. Katzenstein AL. Pathogenesis of "fibrosis" in interstitial pneumonia: an electron microscopic study. Hum Pathol. 1985;16(10):1015-24.

21. Myers JL, Katzenstein AL. Epithelial necrosis and alveolar collapse in the pathogenesis of usual interstitial pneumonia. Chest. 1988;94(6):1309-11.

22. Corrin B, Dewar A. Pathogenesis of idiopathic interstitial pulmonary fibrosis. Ultrastruct Pathol. 1996;20(4):369-71.

23. Fireman E, Shahar I, Shoval S, Messer G, Dvash S, Grief J. Morphological and biochemical properties of alveolar fibroblasts in interstitial lung diseases. Lung. 2001;179(2):105-17.

24. Phan SH. Fibroblast phenotypes in pulmonary fibrosis. Am J Respir Cell Mol Biol. 2003;29(3 Suppl):S87-92.

25. Beon M, Harley RA, Wessels A, Silver RM, LudwickaBradley A. Myofibroblast induction and microvascular alteration in scleroderma lung fibrosis. Clin Exp Rheumatol. 2004;22(6):733-42.

26. Okada A, Tomasetto C, Lutz Y, Bellocq JP, Rio MC, Basset P. Expression of matrix metalloproteinases during rat skin wound healing: evidence that membrane type-1 matrix metalloproteinase is a stromal activator of pro-gelatinase A. J Cell Biol. 1997;137(1):67-77.

27. Parra ER, Silvério da Costa LR, Ab'Saber A, Ribeiro de Carvalho CR, Kairalla RA, Fernezlian SM, et al. Nonhomogeneous density of CD34 and VCAM-1 alveolar capillaries in major types of idiopathic interstitial pneumonia. lung. 2005;183(5):363-73. 
28. Parra ER, Kairalla RA, de Carvalho CR, Capelozzi VL. Abnormal deposition of collagen/elastic vascular fibres and prognostic significance in idiopathic interstitial pneumonias. Thorax. 2007;62(5):428-37.

29. Presta M, Dell'Era P, Mitola S, Moroni E, Ronca R, Rusnati M. Fibroblast growth factor/fibroblast growth factor receptor system in angiogenesis. Cytokine Growth Factor Rev. 2005;16(2):159-78.

30. Renzoni EA, Walsh DA, Salmon M, Wells AU, Sestini $P$, Nicholson AG, et al. Interstitial vascularity in fibrosing alveolitis. Am J Respir Crit Care Med. 2003;167(3):438-43.

\section{About the authors}

\section{Edwin Roger Parra}

Postdoctoral Student. University of São Paulo School of Medicine, São Paulo, Brazil.

\section{Leandro Hideki Otani}

Resident in Radiology. University of São Paulo School of Medicine Hospital das Clínicas, São Paulo, Brazil.

Erika Franco de Carvalho

Pathologist. University of São Paulo School of Medicine, São Paulo, Brazil.

\section{Alexandre Ab'Saber}

Pathologist. University of São Paulo School of Medicine, São Paulo, Brazil.

\section{Vera Luiza Capelozzi}

Associate Professor. Department of Pathology, University of São Paulo School of Medicine - São Paulo, Brazil. 